\title{
Synthesis and Spectroscopic Studies of Zinc (II) Ion and Copper (II) Ion Complexes of 4-Methyl-N-(pyridin-2- yl)benzene Sulphonamide
}

\author{
Kingsley John Orie*, Remy Ukachukwu Duru, Raphael I-oro Ngochindo \\ Department of Pure and Industrial Chemistry, University of Port Harcourt, Port Harcourt, Nigeria
}

\author{
Email address: \\ oriekingsley81@gmail.com (K. J. Orie) \\ ${ }^{*}$ Corresponding author
}

\section{To cite this article:}

Kingsley John Orie, Remy Ukachukwu Duru, Raphael I-oro Ngochindo. Synthesis and Spectroscopic Studies of Zinc (II) Ion and Copper (II) Ion Complexes of 4-Methyl- $N$-(pyridin-2-yl)benzene Sulphonamide. World Journal of Applied Chemistry. Vol. 6, No. 2, 2021 , pp. 19-24. doi: $10.11648 /$ j.wjac.20210602.12

Received: June 14, 2021; Accepted: June 24, 2021; Published: June 29, 2021

\begin{abstract}
Sulphonamide derivative of heteroaromatic compounds has vastly been used as bactericide, fungicide, germicide, antitumor and others in the field of the pharmaceutical industry. Their complexations as revealed by authors are found to enhance the bioactivity of the sulphonamide derivatives except in some cases where bioactive is reduced. 4-methyl-N-(pyridin2-yl)benzene sulphonamide is an important sulphonamide derivative that houses multiple essential moieties like pyridine core, benzene ring, azomethine and sulphonamide. The synthesis and spectra investigation of Zinc (II) ion and Copper (II) ion complexes of 4-Methyl- $N$-(pyridin-2-yl)benzene sulphonamide was achieved by two-step reactions. 2-aminopyridine was sulphonylated via the action of tosyl chloride on 4-aminopyridine in the presence of sodium trioxocarbonate (IV) in an aqueous solvent. The product was washed severally with distilled water and purified with mixed solvent. Thereafter, the product was complexed with $\mathrm{Zn}^{2+}$ and $\mathrm{Cu}^{2+}$ ions. The purity of both the ligand and complexes were confirmed using thin-layer chromatography and melting point analysis. The solubility analysis confirmed the behaviour of the ligand and the complexes in some organic solvents. The structural elucidations were achieved through Ultraviolet Visible spectroscopy (UV-Vis), Fourier Transform Infer-Red (FTIR) spectroscopy, Proton Nuclear Magnetic Resonance ( ${ }^{1}$ HNMR), Carbon-13 Nuclear Magnetic Resonance $\left({ }^{13} \mathrm{CNMR}\right)$ and Electron Spray Ionisation-Mass Spectrometer (ESI-MS). The formation of 1:2 [M: 2L] complex was shown in the elemental analysis data. The molar conductance measurements revealed that all the complexes are nonelectrolyte in nature. The infrared (IR) spectra studies indicated the binding sites of the sulphonamide derivatives ligand with the transition metal ions. The spectra of the complexes showed an absorption shift, with the free ligand of azomethine having the absorption band (1681.98) while that of the complexes, $\mathrm{Zn}$ (II) and $\mathrm{Cu}(\mathrm{II})$ have the absorption bands of $1674.30 \mathrm{~cm}^{-1}$ and $1674.27 \mathrm{~cm}^{-1}$ respectively. The complexation of4-Methyl- $N$-(pyridin-2-yl)benzene sulphonamide may hopefully increase the biological and catalytic potential of the ligand in the pharmaceutical and chemical industries.
\end{abstract}

Keywords: 2-Aminopyridine, Complexation, 4-Methyl- $N$-(pyridin-2-yl)benzenesulphonamide, Tosyl Chloride, Synthesis

\section{Introduction}

In recent years, metal complexes of sulphonamides have attracted considerable attention due to their remarkable antibacterial, antifungal and antitumor activities $[1,2]$. The metal base drug has become growing aspect of research among organic and pharmaceutical chemists; owing to the variety of exciting and valuable drugs which are already in the market $[2,3]$. Complications of organic ligands improve and enhance the biological (antimicrobial activities) and catalytic potential of the ligand (compound) in the pharmaceutical and chemical industries $[4,5]$.

The chemical 4-Methyl-N-(pyridin-2-yl)benzene sulphonamide is an organic compound with the formula $\mathrm{C}_{12} \mathrm{H}_{12} \mathrm{~N}_{2} \mathrm{O}_{2} \mathrm{~S}$. It holds these essential moieties; pyridine, amine, aromatic nucleus and sulphonamide, which are used as an important intermediate in the chemical and medicinal 
industries. The biological potential of4-methyl-N-(pyridin-2yl)benzene sulphonamide, as an antibacterial, antifungal and antitumor has been investigated by the researcher $[5,6]$.

Amongst the component of 4-methyl-N-(pyridin-2yl)benzene sulphonamide, pyridine derivatives, 2aminopyridine is a potential bidentate ligand with two nitrogen donor atoms. It is of great pharmacological importance because of its use in the synthesis of pharmaceuticals, such as antihistamines and antiinflammatory [7]. 2-aminopyridine has also been shown to have a major influence on the formation of transition metal molybdates in which it acts as a buffer and forms weaker complexes with the transition metals, thus preventing their hydrolysis [8, 9].

This research work is focused on the synthesis and spectroscopic investigation of 4-methyl- $N$-(pyridin-2yl)benzene sulphonamide ligand and its complexation with $\mathrm{Cu}$ (II) and $\mathrm{Zn}$ (II) metal ions. The melting point analysis, TLC investigation and solubility test were used to ascertain the purity level of the synthesized ligand and metal complexes.

\section{Materials and Methods}

\subsection{Equipment Used in This Study}

The chemicals 2-aminopyridine, tosyl chloride ethanol, acetic acid, acetone, sodium trioxocarbonate (IV) and others were of analytical grade and were used without further purification. Thin layer chromatography (TLC) was carried out using a Merck pre-coated silica gel plate $(10 \times 10 \mathrm{~cm})$; the Rf value was obtained using a solvent mixture of acetic acid and ethanol in a ratio of 1:2. The chromatogram was visualized using an ultraviolet lamp at $256 \mathrm{~nm}$. The melting point was recorded with Digital Melting Point Electrothermal IA9300X1. The IR spectra were obtained from the FTIR$8400 \mathrm{~S}$ Fourier Transform Infrared spectrophotometer at NARICT Zaria using ATR disc. It was used to identify the functional groups, Liquid Chromatography/Mass Spectrometer was used for molecular formula/mass identification, and Proton Nuclear Magnetic Resonance $\left({ }^{1} \mathrm{HNMR}\right)$ and Carbon-13 Nuclear Magnetic Resonance $\left({ }^{13} \mathrm{CNMR}\right)$ were recorded on a JEOLA-LA-400 MHz-NMR Spectrophotometer at University of Strathclyde, United Kingdom.

\subsection{Experimental Methods}

\subsubsection{Tosylation of Aminopyridine}

The method adopted for the tosylation of 2-aminopyridine was by Rehman et al.,[10] and Abdul-Qaduir et al.,[6] with minor modification. Aminopyridine $(0.053 \mathrm{~mol}, 5 \mathrm{~g})$ and sodium trioxocarbonate (IV) $(1 \mathrm{M}, 20 \mathrm{ml})$ were placed in distilled water $(25 \mathrm{ml})$ and stirred vigorously for 15 minutes. Thereafter, tosyl chloride $(0.053 \mathrm{~mol}, 10 \mathrm{~g})$ was gradually added to the mixture and stirred vigorously at room temperature for 4 hours. After completion of the reaction monitored by $\mathrm{pH}$ change and TLC analysis, few drops of concentrated $\mathrm{HCl}$ were added to adjust the $\mathrm{pH}$ of the solution. This thus led to the precipitation of the product which was washed severally with distilled water and recrystallized with a mixed solvent system of ethanol and water at a ratio of 1:5. The resulting crystal was collected via filtration, washed with distilled water and dried.

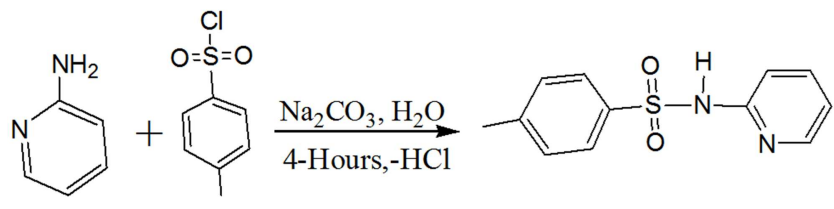

Figure 1. Tosylation of 2-aminopyridine.

\subsubsection{Complexation of Methyl-N-(pyridin-2-yl)benzene Sulphonamide}

A hot ethanolic solution of $\mathrm{C}_{12} \mathrm{H}_{12} \mathrm{~N}_{2} \mathrm{O}_{2} \mathrm{~S}$ (4Mmol) was placed in a boiled ethanolic solution of $\mathrm{Cu}\left(\mathrm{NO}_{3}\right)_{2} \cdot 6 \mathrm{H}_{2} \mathrm{O}$ / $\mathrm{ZnCl}_{2}$ (4Mmol.). The mixture was stirred for 2 hours allowed to stand for 2 hours undisturbed. The precipitate formed was filtered and washed severally with ethanol. The products were recrystallized with a mixed solvent of DMSO and ethanol (1:6). It was allowed to dry at ambient temperature.

$$
\begin{gathered}
\mathrm{M}^{2+}+\mathrm{L}_{\mathrm{A}} \rightarrow\left[\mathrm{M}\left(\mathrm{L}_{\mathrm{A}}\right)_{2}\right] \mathrm{L}_{\mathrm{A}}=\text { Methyl-N-(pyridin-2-yl)benzene sulphonamide } \\
\mathrm{M}^{2+}=\mathrm{Zn}^{2+}, \mathrm{Cu}^{2+}
\end{gathered}
$$

\section{Results and Discussions}

\subsection{Mechanism of the Tosylation of 2-aminopyridine}

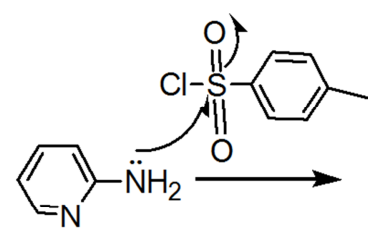

1

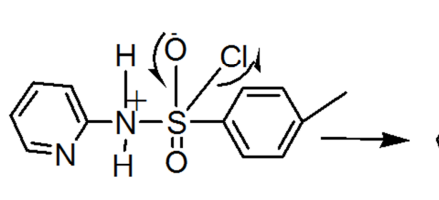

2

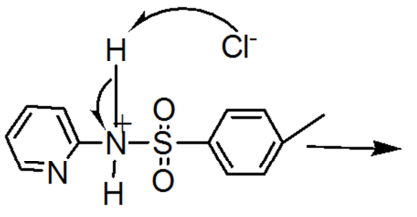

3

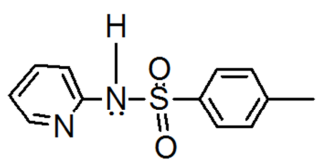

4

Figure 2. Mechanism of tosylated 2-aminopyridine. 
The mechanistic design for this reaction was in line with the view of Lakrout et al., [11]

Stage1 in the mechanism shown above (Figure 1) depicts the action of tosyl chloride on 2-aminopyridine. The amine group in 2-aminopyridine attacks the sulphonyl group with the pi bond electron between sulphur and oxygen moving to oxygen. Stage 2 involves the movement of electron on oxygen to the bond between sulphur and oxygen, and also the departure of chlorine ion as shown in Figure 1. Stage 3 involves the removal of proton by chorine ion to give rise to the expected structure in stage 4 , which in turn represents a monotosylated aminopyridine.

\subsection{NMR Analysis of 4-Methyl-N-(pyridin-2-yl)benzene Sulphonamide}

The ${ }^{1}$ HNMR data in Table 3 represents the chemical shift and coupling constant values of 4-methyl- $\mathrm{N}$-(pyridin-2yl)benzene sulphonamide. The chemical shift within the range of 6.5 to $8.5 \mathrm{ppm}$ confirms the aromatic region [12-14]. The proton with the peak, $2.29 \mathrm{ppm}$ was assigned to the proton of the methyl group in tosyl moieties, and the proton with the chemical shift, $11.03 \mathrm{ppm}$ was assigned to the proton of the sulphonamide moieties $[5,10,14]$. Other ${ }^{1}$ HNMR details of the synthesized product are shown in the table below;

Table 1. Selected Chemical Shift and Coupling Constant Methyl-N-(pyridin-2-yl)benzene sulphonamide.

\begin{tabular}{|c|c|c|c|c|c|c|c|}
\hline Name & Shift & Range & H's & Class & J Const. & Method & Descriptions \\
\hline $1 \mathrm{~A}(\mathrm{~m})$ & 7.52 & $7.56-7.49$ & 1 & $\mathrm{~m}$ & & Peaks & Aromatic proton \\
\hline $2 \mathrm{~B}(\mathrm{~d})$ & 7.33 & $7.35-7.30$ & 1 & $\mathrm{~d}$ & 8.03 & Peaks & Aromatic proton \\
\hline $3 \mathrm{C}(\mathrm{d})$ & 7.19 & $7.21-7.17$ & 1 & $\mathrm{~d}$ & 8.68 & Peak & Aromatic proton \\
\hline 4D (d) & 7.15 & $7.16-7.12$ & 1 & $\mathrm{~d}$ & 7.85 & Peaks & Aromatic proton \\
\hline 5 E (ddd) & 6.91 & $6.94-6.88$ & 1 & ddd & $1.00,5.46,6.85$ & Peaks & Aromatic proton \\
\hline $6 \mathrm{~F}(\mathrm{~m})$ & 7.76 & $7.79-7.74$ & 1 & $\mathrm{~m}$ & & Peak & Aromatic proton \\
\hline $7 \mathrm{G}(\mathrm{dd})$ & 8.05 & $8.07-8.02$ & 1 & dd & $1.88,5.63$ & Peaks & Aromatic proton \\
\hline $9 \mathrm{~J}(\mathrm{~s})$ & 11.03 & $11.64-10.57$ & 1 & $\mathrm{~s}$ & & Peaks & Amine \\
\hline
\end{tabular}

The chemical shift within the range of 114.32-152.89 ppm confirms the presence of an aromatic ring while $21.33 \mathrm{ppm}$ indicates the presence of a methyl group attached to the aromatic ring $[14,15]$.

\subsection{Solubility Analysis of Ligand and Its Complexes}

The solubility of the ligand $\left(\mathrm{C}_{12} \mathrm{H}_{12} \mathrm{~N}_{2} \mathrm{O}_{2} \mathrm{~S}\right)$ and the complexes, $\left[\mathrm{Zn}\left(\mathrm{C}_{12} \mathrm{H}_{12} \mathrm{~N}_{2} \mathrm{O}_{2} \mathrm{~S}\right)_{2}\right]$ and $\left[\mathrm{Cu}\left(\mathrm{C}_{12} \mathrm{H}_{12} \mathrm{~N}_{2} \mathrm{O}_{2} \mathrm{~S}\right)_{2}\right.$ was studied in various solvents. The ligand was soluble in DMSO, DMF, Acetic acid and ethanol, but insoluble in water, hexane, acetone and ethyl acetate. The complexes are insoluble in water, hexane, acetone and ethyl acetate but were soluble in DMSO, DMF and Acetic acid (see table 2). Their solubility is a result of the interaction between the hydrogen ion in the complexes and the oxygen atom in the solvent which results in the formation of a hydrogen bond $[6,16]$.

Table 2. Solubility of Ligand and Complexes in Different Solvents.

\begin{tabular}{|c|c|c|c|c|c|c|c|c|c|}
\hline Serial No & Ligand/ Complexes & Hex & EtOH & Ace & EA & $\mathbf{A A}$ & DMF & DMSO & $\mathrm{H}_{2} \mathrm{O}$ \\
\hline 1 & $\mathrm{C}_{12} \mathrm{H}_{12} \mathrm{~N}_{2} \mathrm{O}_{2} \mathrm{~S}$ & Insol. & Sol. & Insol. & Insol. & Sol. & Sol. & Sol. & Insol. \\
\hline 2 & {$\left[\mathrm{Zn}\left(\mathrm{C}_{12} \mathrm{H}_{12} \mathrm{~N}_{2} \mathrm{O}_{2} \mathrm{~S}\right)_{2}\right]$} & Insol. & Insol. & Insol. & Insol. & Sol. & Sol. & Sol. & Insol \\
\hline 3 & {$\left[\mathrm{Cu}\left(\mathrm{C}_{12} \mathrm{H}_{12} \mathrm{~N}_{2} \mathrm{O}_{2} \mathrm{~S}\right)_{2}\right]$} & Insol. & Insol. & Insol. & Insol. & Sol. & Sol. & Sol. & Insol. \\
\hline
\end{tabular}

\subsection{Analytical Data of Ligand and Complexes}

4-Methyl-N-(pyridin-2-yl)benzene sulphonamide and its metal(II) complexes shows various shades of colours ranging from offwhite, white and light blue(see table 1) for the ligand and the complexes of $\mathrm{Zn}$ (II) and $\mathrm{Cu}$ (II) respectively. The ligand and complexes of $\mathrm{Zn}$ (II) and $\mathrm{Cu}$ (II) obtained gave a sharp melting point indicating the isolation of fairly pure complexes. The ligand has the melting of $180^{\circ}-182^{\circ} \mathrm{C}$, while that of the $\mathrm{Zn}^{2+}$ and $\mathrm{Cu}{ }^{2+}$ complexes as shown in Table 1 are $207-209^{\circ} \mathrm{C}$ and $156-158^{\circ} \mathrm{C}$ [6, 17]. The molar conductance of the complexes was determined in DMSO. It was found to be $13.3,14.8$ and $16.2 \Omega^{-1} \mathrm{~cm}^{-2} \mathrm{~mol}^{-1}$ for the ligand, $\mathrm{Zn}$ and $\mathrm{Cu}$ complexes respectively. The values indicate that no anions are present outside the coordination sphere in all the complexes. Thus, suggest their non-electrolytic nature [18, 19]. The sulphonamide and its metal (II) complexes were prepared in good yield, ranging from $50-80 \%$ [10], and are presented in Tables 3 .

Table 3. Physical Properties of Ligand and Complexies.

\begin{tabular}{|c|c|c|c|c|c|c|c|}
\hline \multirow{2}{*}{ Compound } & \multirow{2}{*}{ Colour } & \multirow{2}{*}{$\begin{array}{l}\text { Mol. } \\
\text { weight }\end{array}$} & \multirow{2}{*}{$\begin{array}{l}\text { Melting } \\
\text { point, }{ }^{\circ} \mathrm{C}\end{array}$} & \multirow{2}{*}{$\%$ Yield } & \multirow{2}{*}{$\begin{array}{l}\text { Molar conductivity } \\
\Omega-{ }^{1} \mathrm{~cm}^{-2} \mathrm{~mol}^{1}\end{array}$} & \multicolumn{2}{|c|}{ TLC Analysis } \\
\hline & & & & & & $\mathbf{R}_{\mathrm{F}}$ Value & Solvent mixture/ ratio \\
\hline $\mathrm{C}_{12} \mathrm{H}_{12} \mathrm{~N}_{2} \mathrm{O}_{2} \mathrm{~S}$ & Offwhite & 249.1 & $180-182$ & 60 & 13.3 & 0.68 & AA:ETOH: $\mathrm{H}_{2} \mathrm{O}(2: 1: 1)$ \\
\hline$\left[\mathrm{Zn}\left(\mathrm{C}_{12} \mathrm{H}_{12} \mathrm{~N}_{2} \mathrm{O}_{2} \mathrm{~S}\right)_{2}\right]$ & white & 561.4 & $207-209$ & 77 & 14.8 & 0.72 & DMF:ACE (2:1) \\
\hline$\left[\mathrm{Cu}\left(\mathrm{C}_{12} \mathrm{H}_{12} \mathrm{~N}_{2} \mathrm{O}_{2} \mathrm{~S}\right)_{2}\right]$ & Ligh blue & 560.3 & $156-158$ & 89 & 16.2 & 0.75 & DMF:ACE (2:1) \\
\hline
\end{tabular}

Further characterization of the sulphonamide derivatives and its complexes were achieved via ESI-MS analysis. The anticipated molecular weight of the ligand was estimated at 248.3 while the molecular ion peak of the ligand from the 
ESI-MS analysis was 249.1. The complexes have the molecular weight of 561.4 and 560.3 for zinc (II) and copper (II) complexes respectively. The molecular mass obtained from ESI-MS analysis agreed with the anticipated proposed product and is confirmed by the FTIR and NMR analysis structural elucidation $[6,17,20]$.

\subsection{Elemental Analysis of the Ligand and Its Complexes}

Elemental analysis of the ligand and its complexes are listed in Table 4. The data were in agreement with the ESIMS estimation and the proposed empirical formula of the complexes [21].

Table 4. Elemental Analysis of the Ligand and Complexies.

\begin{tabular}{|c|c|c|c|c|c|c|c|}
\hline \multirow{2}{*}{ compounds } & \multirow{2}{*}{ Mol. weight } & \multicolumn{6}{|c|}{ Analysis Found (calculated)\% } \\
\hline & & $\mathbf{M}$ & $\mathbf{C}$ & $\mathbf{H}$ & $\mathbf{N}$ & $\mathbf{O}$ & $\mathbf{S}$ \\
\hline $\mathrm{C}_{12} \mathrm{H}_{12} \mathrm{~N}_{2} \mathrm{O}_{2} \mathrm{~S}$ & 249.1 & - & $57.56(57.81)$ & $5.09(4.82)$ & $11.80(11.24)$ & $13.46(12.85)$ & $11.89(12.85)$ \\
\hline$\left[\mathrm{Zn}\left(\mathrm{C}_{12} \mathrm{H}_{12} \mathrm{~N}_{2} \mathrm{O}_{2} \mathrm{~S}\right)_{2}\right]$ & 561.4 & $11.48(11.63)$ & $50.79(51.30)$ & $4.64(4.28)$ & $9.85(9.98)$ & $11.66(11.40)$ & $11.58(11.40)$ \\
\hline$\left[\mathrm{Cu}\left(\mathrm{C}_{12} \mathrm{H}_{12} \mathrm{~N}_{2} \mathrm{O}_{2} \mathrm{~S}\right)_{2}\right]$ & 560.3 & $11.55(11.42)$ & $52.37(51.40)$ & $4.62(4.28)$ & $10.27(10.00)$ & $10.55(11.43)$ & $10.64(11.42)$ \\
\hline
\end{tabular}

\subsection{Electronic Analysis of Ligand and Complexes}

The electronic transition of the pure sulphonamide, zinc (II) and Copper (II) ion were recorded in DMSO solution at room temperature between 200-1100 $\mathrm{nm}$. The absorption below $250 \mathrm{~nm}$ was obscured in the DMSO spectra due to solvent absorption. The band at 225-203 nm corresponds to the $\pi \rightarrow \pi^{*}$ transition of the benzene rings, while the absorptions at 299-256 nm and 345-301 nm were assigned, respectively, to the $\pi \rightarrow \pi^{*}$ and $\mathrm{n} \rightarrow \pi^{*}$ transitions of the azomethine group, $\mathrm{HC}=\mathrm{N}$ of 2-aminopyridine. The spectra of copper (II) complex exhibits a prominent band at 513-307 $\mathrm{nm}$ due to ligand to $\mathrm{Cu}(\mathrm{II})$ charge transfer transition (LMCT), while the broad band at 715-629 nm region corresponds to the $d-d$ transition of the $\mathrm{Cu}$ (II) complexes [21]. The spectra of the zinc (II) complex exhibits a prominent band at 375 $307 \mathrm{~nm}$ due to ligand to $\mathrm{Zn}(\mathrm{II})$ charge transfer transition (LMCT). However, the electronic spectrum of the zinc (II) complex does not show any band that corresponds to the central metal ion and the bands observed are mainly due to the ligands and metal-to-ligand interactions. This could be attributed to the filled d orbital in the zinc (II) atom $[22,23]$.

Table 5. Selected FT IR Absorption Bands for gand and complexes.

\begin{tabular}{lll}
\hline compound & Adsorption nm & Band assignment \\
\hline $\mathrm{C}_{12} \mathrm{H}_{12} \mathrm{~N}_{2} \mathrm{O}_{2} \mathrm{SN}_{2} \mathrm{O}_{2} \mathrm{~S}$ & $225-203,299-256,345-301$ & $\pi \rightarrow \pi^{*}, \mathrm{n} \rightarrow \pi^{*}$ \\
{$\left[\mathrm{Zn}\left(\mathrm{C}_{12} \mathrm{H}_{12} \mathrm{~N}_{2} \mathrm{O}_{2} \mathrm{~S}\right)_{2}\right]$} & $375-307$ & $\pi \rightarrow \pi^{*}, \mathrm{n} \rightarrow \pi^{*}$ \\
{$\left[\left[\mathrm{Cu}\left(\mathrm{C}_{12} \mathrm{H}_{12} \mathrm{~N}_{2} \mathrm{O}_{2} \mathrm{~S}\right)_{2}\right]\right.$} & $513-307,715-629$ & $\pi \rightarrow \pi^{*}, \mathrm{n} \rightarrow \pi^{*}, \mathrm{~d} \rightarrow \mathrm{d}$ \\
\hline
\end{tabular}

$\pi \rightarrow \pi^{*}, \mathrm{n} \rightarrow \pi^{*}, \mathrm{~d} \rightarrow \mathrm{d}$ : Electronic transition from highest occupy molecular orbital(HOMO) to lowest uncoccupy molecular orbital(LUMO)

\subsection{FTIR Investigations of Synthesized Ligand and Metal Complexes}

Table 6. Selected FT IR Absorption Bands for gand and complexes.

\begin{tabular}{lllllll}
\hline S/no & Ligand/complex & $\mathbf{V}_{\mathbf{N}-\mathbf{H}}$ & $\mathbf{V}_{\mathbf{C}=\mathbf{N}}$ & $\mathbf{V}_{\mathbf{C}=\mathbf{C}}$ & $\mathbf{V}_{\mathbf{C H}}$ \\
\hline 1 & $\left(\mathrm{C}_{12} \mathrm{H}_{12} \mathrm{~N}_{2} \mathrm{O}_{2} \mathrm{~S}\right)$ & 3734.31, & 1681.98 & 1519.92 & 2924.18 \\
2 & {$\left[\mathrm{Zn}_{\left.\left(\mathrm{C}_{12} \mathrm{H}_{12} \mathrm{~N}_{2} \mathrm{O}_{2} \mathrm{~S}\right)_{2}\right]}\right.$} & 3857.76 & 1674.30 & 1527.67 & 2908.75 \\
3 & {$\left[\mathrm{Cu}\left(\mathrm{C}_{12} \mathrm{H}_{12} \mathrm{~N}_{2} \mathrm{O}_{2} \mathrm{~S}\right)_{2}\right]$} & 3865.58 & 1674.27 & 1527.96 & 1010.73 \\
\hline
\end{tabular}

The important IR spectral bands of the ligand and its metal complexes were given in Table 4 . The ligand contains three potential donor sites: the heterocyclic nitrogen of azomethine, the oxygen of sulphonamide and the nitrogen of sulphonamide $[11,24,25]$. The IR frequency band of the ligand at $3734.13 \mathrm{~cm}^{-1}$ was assigned to nitrogen of the sulphonamide, the band at $1249.91 \mathrm{~cm}^{-1}$ was assigned to the sulphonamide oxygen and the band at $1681.98 \mathrm{~cm}^{-1}$ was assigned to the heterocyclic azomethine nitrogen [19]. The evidence that the imine nitrogen is coordinated to zinc (II) ion is depicted in the vibration frequency band of $1674.30 \mathrm{~cm}^{-}$ ${ }^{1}$ and that of the copper (II) is indicated in thee with the vibration frequency band of $1674.27 \mathrm{~cm}^{-1}$. This observation is in line with the azomethine $(\mathrm{C}=\mathrm{N})$ frequency range of $1643.41-1575 \mathrm{~cm}^{-1}$ observed [26, 27]. Other important frequency bands of the ligand and their complexes are shown in Table 4.

\section{Conclusion}

This research work, therefore, reports the synthesis of the ligand, 4-methyl-N-(pyridin-2-yl) benzene sulphonamide via coupling of 2-aminopyridine and tosyl chloride. The ligand was complexed with $\mathrm{Zn}$ (II) and $\mathrm{Cu}(\mathrm{II})$ ions. The ligand and metal complexes were characterized with elemental analysis, electronic, molar conductance, FTIR, ${ }^{1} \mathrm{HNMR}$ and ${ }^{13} \mathrm{CNMR}$, ESI-MS and other physical measurements. The spectroscopic studies reveal the composition, different modes of bonding, electronic transition, the different chemical environment of $\mathrm{C}$ and $\mathrm{H}$ atoms and the electronic state of the metal atoms. The FTIR investigation depicted that the metals were coordinated through the azomethine hetero-nitrogen. The method employed in this synthesis and the compound synthesized is a viable potential source of knowledge for chemists since 
there is no possible evidence of the existence of the method and the compound synthesized in literature.

\section{Conflict of Interest}

The authors declare that they have no competing interests.

\section{Acknowledgements}

The authors therefore remain grateful to the department pure and industrial chemistry university Port Harcourt, Nigeria for giving me this opportunity.

\section{References}

[1] Omar, M., Mohamed, G. and Hindy, A., (2006). Transition metal complexes of heterocyclic Schiff base: Biological activity, spectroscopic and thermal characterization. Journal thermal analysis and calorimetry, 86 (2), 315-325. https://doi.org/10.1007/s10973-006-7095-3

[2] Moreno, D., Daier, V., Palopoli, C., Tuchagues, J. P., Signorella, S. (2010). Synthesis, characterization and antioxidant activity of water soluble MnIII complexes of sulphonato-substituted Schiff base ligands. Journal inorganic $\begin{array}{llll}\text { Biochemistry } & 104 & \text { (5): }\end{array}$ https://doi.org/10.1016/j.jinorgbio.2009.12.016

[3] Dhayabaran, V. V., Prakash, T. D., Renganathan, R., Friehs, E., Bahnemann, D. W. (2017). Novel Bioactive Co (II), Cu (II), Ni (II) and Zn (II) Complexes with Schiff base ligand derived from histidine and 1, 3-Indandione: synthesis, structural elucidation, biological investigation and Docking analysis. Journal fluorine 27 (1): 135-150. https://doi.org/10.1007/s10895-016-1941-x

[4] Ogunniran, K. O., Ajanaku, K. O., James, O. O., Ajani, O. O., Nwinyi, O., Allensela, M. A. (2008). Fe (III) and Co (II) complexes of mixed antibiotics: synthesis, characterization, antimicrobial potential and their effect on alkaline phosphatase activities of selected rat tissues. International Journal Physical Science 3 (8): 177-182.

[5] Nzikaye, 1. S., Akpan, I. J., Adams, E. C. (2017). Synthesis, FTIR and electronic spectra studies of metal (II) complexes of pyrazine-2-carboxylic acid derivative, Journal Medicinal Chemistry 7 (11): 321-323. DOI: 10.4172/2161-0444.1000475.

[6] Abdul-Qadir. M., Ahmed, M., Aslam, H., Waseem, S. and Shafiq, M. I. (2015). Amidine sulphonamides and benzene sulphonamides: synthesis and their biological evaluation Journal of Chemistry. 2015. https://doi.org/10.1155/2015/524056

[7] Hossain, M., Bashar, A., Khan, N., Roy, P. K., Mannan, A., Ali, S. and Farooque, A. (2018). Physical and spectral characterization of $\mathrm{Ni}$ (II) $\mathrm{Cu}$ (II) $\mathrm{Co}$ (II) and $\mathrm{Cd}(\mathrm{II})$ complexes with Schiff Base of salicylaldehyde and 2-aminopyridine towards potential microbial application. American Journal of Applied Chemistry 6 (4): 147-155. htt. doi: 10.11648/j.ajac.20180604.13.

[8] Odabasoglu, M., Buyukgungor, O., Turgut, G., Karadag, A., Bulak, E. and Lonnecke, P. (2003). "Crystal structure, spectral and thermal properties of 2-aminopyridinium adipate monoadipic acid dehydrate. Journal of Molecular Structure
648 (1-2): 133-138. https://doi.org/10.1016/S00222860(02)00720-2

[9] Pavani, K. and Ramanan, A. (2005) "Influence of 2aminopyridine on the formation of molybdates under hydrothermal conditions," European Journal Inorganic Chemistry 15: 3080-3087. https://doi.org/10.1002/ejic.200500092

[10] Rehman, H., Abdul Qadir, M., Shad, H. A. and Khan, Z. I. (2017). One pot synthesis of some novel sulphonamide derivatives containing- $\mathrm{NH}_{2}$ group: spectral characterization and biological evaluation. Medicinal Chemistry 7: 252-6. htt. doi: 10.4172/2161- 0444.1000465.

[11] Lakrout, S., K'tir, H., Amira, A., Berredjem, M. and Aouf, N. E. (2014). A simple and eco-sustainable method for the sulfonylation of amines under microwave-assisted solvent-free conditions. RSC Advances, 4 (31): 16027-16032.

[12] Alsughayer, A., Elassar, A. Z., Mustafa, S. and Al Sagheer, F. (2011). Synthesis, structure analysis and antibacterial activity of new potent sulfonamide derivatives. Journal of Biomaterial Nanobiotechnolgy 2: 144-149. htt. doi: 10.4236/jbnb.2011.22018.

[13] Deng, X. and Mani, N. S. (2006). A facile, environmentally benign sulphonamide synthesis in water, Green Chemistry 8 (9): 835-838. https://doi.org/10.1039/B606127C

[14] Qadir, M. A., Ahmed, M. and Khaleeq, A. (2016). Synthesis, antibacterial and antifungal possession of amino acids containing sulphonamide moieties Pakistan Journal Pharm sciencen 29 (5): 1609-13.

[15] Mishra, A. P., Mishra, R. K., Pandey, M. D. (2011). Synthetic, spectral, structural and antimicrobial studies of some Schiff bases 3-d metal complexes. Russian Journal of Inorganic Chemistry, $\quad 56 \quad$ (11): $1757-1764$. https://doi.org/10.1134/S0036023611080195

[16] Ananthalakshmi, S., Kavitha, R., Kiruthika, A. and Kalaivani. S. (2014). Synthesis, characterization and antimicrobial studies of tosyl esters of carboxylic acid. Int J Sci Research Publiction 4: 1-14.

[17] Alim, A., Zahan, K. E., Haque, M. And Tarafder, M. (2015). Synthesis and characterization of some metal complexes of $\mathrm{Cu}$ (II), Ni (II), Zn (II), Cd (II), Sn (II), Co (II), Sb (III) and Fe (III) containing bidentate Schiff base of Smdtc. Science Journal of Chemistry 3 (3): 35-39. doi: 10.11648/j.sjc.20150303.11.

[18] Taghreed, H., Al-Noor, M. R., and Aziz, A. T. (2014). Synthesis, characterization and antimicrobial activities of $[\mathrm{Fe}(\mathrm{II}), \quad \mathrm{Co}(\mathrm{II}), \quad \mathrm{Ni}(\mathrm{II}), \quad \mathrm{Cu}(\mathrm{II}), \quad$ and $\mathrm{Zn}(\mathrm{II})]$ mixed ligandcomplexes schiff base derived from ampicillin drug and 4(dimethylamino)benzaldehyde with nicotinamide. International Journal of Technical Research and Applications e-2 (4): 187-192.

[19] Oluwatoosin, B., Agbaje, A., Sherifat, M. W., Osowole, A. A. (2014). Synthesis, spectroscopic characterisation and antimicrobial activities of some mixed drug metal (II) complexes of Sulfamethoxazole and Paracetamol. Academic editor JC 2 (1) 140-143.

[20] Sharif, S. A. I., El-Tajoury, A. N. and Elamari, A. A. (2011). Preparation and antibacterial activity of mixed ligand complexes of $\mathrm{Co}$ (II), $\mathrm{Ni}$ (II), $\mathrm{Cu}$ (II) and Cd (II) derived from 1-phenylazo-2-naphthol and salicylaldehyde. E-J Chemistry 8 (1): 43-48. https://doi.org/10.1155/2011/519273 
[21] Muhammad, A. S., \& Shedewo, O. A. (2015). Sythesis, characterization and antibacterial properties of nickel (ii) Schiff base complex derived from benzoin and amino benzoic acid. Bayero Journal of Pure and Applied Sciences, 8 (1), 3336. DOI: 10.4314/bajopas.v8i1.7

[22] Machura, B. (2004). Electronic structure and UV-Vis spectroscopy of [Re (NO) Br3 (PPh3) 2] and [Re (NO) Br3 (OPPh3) 2] complexes. Polyhedron, 23 (15), 2363-2371. https://doi.org/10.1016/j.poly.2004.07.021

[23] Dhaveethu, K., Ramachandramoorthy, T., \& Thirunavukkarasu, K. (2013). Microwave-assisted Synthesis of Mixed Ligand Complexes of $\mathrm{Zn}$ (II), Cd (II) and $\mathrm{Hg}$ (II) Derived from 4-aminopyridine and Nitrite Ion: Spectral, Thermal and Biological Investigations. Journal of the Korean $\begin{array}{llll}\text { Chemical Society, } & 57 & \text { (3), } & \text { 341-351. }\end{array}$ Htts//doi.org/10.5012/jcs.2013.57.2013.3.341

[24] Khalil, M. H., Ismail, E. H., Mohamed, G. G., Zayed, E. M. and Badr, A. (2012). Synthesis and characterization of a novel schiff base metal complexes and their application in determination of iron in different types of natural water. Open Journal of Inorganic Chemistry 2 (2): 13-21 https://doi.org/10.1155/2011/519273

[25] Chohan, Z. H. (2008). Metal-based sulfonamides: Their preparation, characterization and in-vitro antibacterial, antifungal \& cytotoxic properties. X-ray structure of $4-[(2-$ hydroxybenzylidene) amino] benzenesulfonamide. Journal Enzyme Inhibition Medicinal Chemistry, 21 (1): 120-130. https://doi.org/10.1080/14756360701384195

[26] Ahmed, A. A., Umar, H. A, Yunusa, Y. and Adegbemiga, B. (2017), Synthesis and Characterization of Cobalt (II) and Nickel (II) Complexes with a Schiff Base Derived from 2aminophenol and 4-(n,n-dimethylamino)benzaldehyde. International Journal of Science and Applied Research (IJSAR) 2 (3) $587-593$.

[27] Rehman, W., Baloch, M. and Badshah, A (2008). Synthesis, Spectral characterization and Bio-Analysis of some Organotin(IV) Complexes. European Journal of Medicinal Chemistry, 43: 2380-2385. 